\title{
DETERMINATION OF BIOLOGICAL ACTIVITIES OF THREE MARINE ALGAE COLLECTED FROM VISAKHAPATNAM COAST
}

\author{
SATYALAKSHMI $\mathbf{S}^{*}$ \\ Department of Pharmacy, Pharmaceutical Biotechnology Division, Vignan Institute of Pharmaceutical Technology, Visakhapatnam, \\ Andhra Pradesh, India. Email: satyalaxmi148@gmail.com
}

Received: 20 June 2017, Revised and Accepted: 06 September 2017

\section{ABSTRACT}

Objective: Determination of biological activities of marine algae collected from the Visakhapatnam coastal region.

Methods: Antibacterial activity of algal extracts determined by the well diffusion method, antioxidant activity was determined by reducing power (RP) method and 1,1-diphenyl-2-picryl-hydrazil (DPPH) radical scavenging method finally anti-inflammatory activity was determined by human red blood cell stabilization method and egg albumin method.

Results: Methanolic extracts of three algae have potential inhibition activity against Escherichia coli, Bacillus subtilis, Pseudomonas aeruginosa, and Staphylococcus aureus. Green alga Enteromorpha compressa has better antioxidant activity compared to the Gracilaria arcuata and Ulva fasciata when tested in RP and DPPH method. $U$. fasciata found good anti-inflammatory activity among the selected three algae.

Conclusion: The three tested algae exhibited significant antibacterial and antioxidant activity compared to anti-inflammatory activity. These bioactive compounds containing macroalgae may find their commercial potential in medicine, food, and cosmetic industry.

Keywords: Visakhapatnam coast, Anti-inflammatory, Antioxidant, Antibacterial, 1, 1-diphenyl-2-picryl-hydrazil, Egg albumin.

(c) 2017 The Authors. Published by Innovare Academic Sciences Pvt Ltd. This is an open access article under the CC BY license (http://creativecommons. org/licenses/by/4. 0/) DOI: http://dx.doi.org/10.22159/ajpcr.2017.v10i12.20857

\section{INTRODUCTION}

Marine algae are the good and the alternative source with many pharmacological and biological activities to provide health benefits to the public. Macroalgae are the most important group to derive nutraceuticals, which may be used in the treatment of chronic diseases such as gastric ulcer, rheumatoid arthritis, cancer, hypertension, and asthma. The antioxidant activity of macroalgae has been proposed to play roles in various pharmacological activities, especially for antiaging and anti-inflammatory effects [1].

Marine macroalgae are gaining importance in present days because of their vast applications in medicine with antimicrobial [2], antiviral [3], anti-allergic [4], anticoagulant [5], anticancer [6], antifouling [7], and antioxidant activities [8]. Metabolites of macroalgae have been used in pharmaceutical industries - alginates and carrageenan as gelling agents, carotene, chlorophyll as pigments and glycerol as a solvent $[9,10]$.

Intertidal areas are more favorable for seaweed growth in the Indian waters. Macroalgae availability is more wherever the rocks and corals distribution is high. The substrata provide good support for attachment of algae for proper utilization of sunlight for photosynthesis and to absorb nutrients from water resources [11].

Macroalgae are the alternative source which provides several bioactive components used in the treatment of different diseases and disorders. Hence, in the present investigation to study the biological activities such as antibacterial, antioxidant, and anti-inflammatory activity three marine macroalgae were collected from Tenneti Park and Yarada beach, Visakhapatnam region in the month of January 2017.

\section{METHODS}

Collection of marine algae

For screening of biological activity of marine algae, the study area considered was the coast around Visakhapatnam, Andhra Pradesh.
Visakhapatnam is the large commercial and industrial area, and it is located on the Coromandel Coast of Bay of Bengal. Live and healthy marine algae were collected from the coast of Yarada and Tenneti park in sterile and spacious bottles containing half of the amount of seawater. Immediately these algal samples were sent to Botany Department of Andhra University for their identification. Three algae were identified as Enteromorpha compressa, Gracilaria arcuata, and U. fasciata by Dr. G. Mohan Narasimha Rao, Professor of Botany Department, and Andhra University, to whom the authors are very indebted.

\section{Preparation of extracts}

The samples were cleaned several times with water to remove sand, mud, and attached fauna and then dried in room temperature $\left(28^{\circ} \mathrm{C}-30^{\circ} \mathrm{C}\right.$, low humidity) for 3 weeks. The dried algae materials were homogenized to a fine powder and extracted using 3 times of its weight with methanol and 4 times of its weight with chloroform for $72 \mathrm{hrs}$ at room temperature and mixed at regular intervals. After $72 \mathrm{hrs}$ the sample dissolved in each solvent was filtered using Whatman filter paper to separate the filtrate. The filtrate was concentrated by rotary evaporation at $45-50^{\circ} \mathrm{C}$ and kept at $4^{\circ} \mathrm{C}$ until further use.

\section{Determination of biological activities of algal extracts} Antibacterial activity

Pure cultures of Escherichia coli, Pseudomonas aeruginosa, Staphylococcus aureus, and Bacillus subtilis were used as test organisms for checking the antibacterial activity.

Antibacterial activity was assayed using diffusion method of making wells. $20 \mathrm{~mL}$ of the sterilized media was inoculated with $18 \mathrm{hrs}$ culture of test organism at $40^{\circ} \mathrm{C}$ and poured into a sterilized Petri dish and allowed to solidify at room temperature. Similarly, inoculation and pouring were done separately for each test microorganism on the NA plates and left for a few minutes to allow complete solidification of the media. In each of these plates, $5 \mathrm{~mm}$ diameter wells were made at the center using an appropriate size sterilized cork borer. Different algal 
extracts $(1000 \mu \mathrm{g} / \mathrm{mL})$ were added to the respective wells on the NA plates and allowed to diffuse at room temperature for 30 minutes. Only the solvents were added as a control to check their effect on test organisms. Then, these plates were kept in incubation at $37^{\circ} \mathrm{C}$ for $24 \mathrm{hrs}$. After incubation, a clear zone was observed around the well, which was the evidence of the presence of antibacterial active compounds in the algal extracts. The diameters of the zone of inhibition were measured in millimeters (including the diameter of the well). Algae extracts are further used for determination of antioxidant and anti-inflammatory activities.

\section{Determination of antioxidant activity}

Reducing power method (RP)

An increase in the absorbance of this method indicates an increase in the antioxidant activity of the algal extract. In this method, antioxidant compound forms a colored complex with potassium ferricyanide, trichloroacetic acid and ferric chloride, which is measured at $700 \mathrm{~nm}$. Increase in absorbance of the reaction mixture indicates the RP of the samples [12]. In the method described by Oyaizu [13] $2.5 \mathrm{~mL}$ of $0.2 \mathrm{M}$ phosphate buffer ( $\mathrm{pH} 6.6)$ and $2.5 \mathrm{~mL}$ of $\mathrm{K}_{3} \mathrm{Fe}(\mathrm{CN})_{6}(1 \% \mathrm{w} / \mathrm{v})$ are added to $1.0 \mathrm{~mL}(1000 \mu \mathrm{g})$ of sample dissolved in distilled water. The resulting mixture is incubated at $50^{\circ} \mathrm{C}$ for 20 minutes, followed by the addition of $2.5 \mathrm{~mL}$ of trichloroacetic acid $(10 \% \mathrm{w} / \mathrm{v})$. The upper layer of the solution $(2.5 \mathrm{~mL})$ is collected by centrifugation at $3000 \mathrm{rpm}$ for 10 minutes, mixed with distilled water $(2.5 \mathrm{~mL})$ and $0.5 \mathrm{~mL}$ of $\mathrm{FeCl}_{3}$ $(0.1 \%, w / v)$. Against a blank sample, the absorbance of the reaction mixture was measured at $700 \mathrm{~nm}$. Algae extract showing significant RP activity was used for determination of antioxidant activity by the 1 , 1-diphenyl-2-picryl-hydrazil (DPPH) radical scavenging method.

\section{DPPH radical scavenging method}

The free radical scavenging activity of algal extracts showing highest RP activity was determined by the method of Zhang et al. [14] using DPPH. DPPH $0.1 \mathrm{mM}$ concentration was prepared in ethanol. This solution $(1 \mathrm{~mL})$ was added to $3 \mathrm{~mL}$ of different compounds in methanol at different concentration $(200,100,50,25$, and $12.5 \mu \mathrm{g} / \mathrm{ml})$. All the contents were shaken vigorously and kept for incubation at room temperature for 30 minutes. The color change was measured at $517 \mathrm{~nm}$ using a spectrophotometer. Ascorbic acid was used as reference standard sample, and the experiment was done for 3 times. The lower absorbance of the reaction mixture indicated higher free radical activity. The percent DPPH scavenging effect was calculated using the following equation.

DPPH scavenging effect (\%) or percent inhibition $=A_{0}-A_{1} / A_{0} \times 100$

Where $A_{0}$ was the absorbance of control reaction and $A_{1}$ was the absorbance in the presence of test or standard sample.

\section{Determination of anti-inflammatory activity}

\section{Human red blood cell (HRBC) stabilization method}

The HRBC membrane stabilization method was used to study the in vitro anti-inflammatory activity of algae extract. Blood was collected from six healthy human volunteers. It was mixed with the same volume of sterilized alsever solution containing $2 \%$ dextrose, $0.8 \%$ sodium citrate, $0.5 \%$ citric acid, and $0.42 \%$ sodium chloride in water. The blood was then centrifuged at $3000 \mathrm{rpm}$ for 20 minutes, and packed cells were separated. The packed cells were washed with isosaline $0.85 \%$, $\mathrm{pH} 7.2$ ) and a $10 \% \mathrm{v} / \mathrm{v}$ suspension was made with isosaline. This HRBC suspension was used for the estimation of anti-inflammatory property. $1 \mathrm{ml}$ of different algal extracts and diclofenac sodium were separately mixed with $1 \mathrm{~mL}$ of phosphate buffer $(0.15 \mathrm{M}, \mathrm{pH} 7.4)$, $2 \mathrm{~mL}$ of hypo saline $(0.36 \%$ ), and $0.5 \mathrm{~mL}$ of HRBC suspension. $2 \mathrm{~mL}$ distilled water was used as the control instead of hyposaline. All the assay mixture was incubated at $37^{\circ} \mathrm{C}$ for 30 minutes and centrifuged at $3000 \mathrm{rpm}$ for 20 minutes. The supernatant liquid was decanted, and the hemoglobin content in the supernatant solution was estimated using spectrophotometer at $560 \mathrm{~nm}$ [15].
The percentage hemolysis was calculated using the following formula:

$\%$ Hemolysis $=$ OD of test $/$ OD of control $\times 100$

The following formula was used for calculation of the percentage of HRBC membrane stabilization or protection:

$\%$ Protection $=100-\mathrm{OD}$ of test $/ \mathrm{OD}$ of control $\times 100$

\section{Egg albumin method}

The reaction mixture was prepared by adding $0.2 \mathrm{~mL}$ of egg albumin, which was collected from fresh hen's egg, $2.5 \mathrm{~mL}$ of phosphate buffered saline (PBS, pH 6.4), and $2 \mathrm{~mL}$ of algal extract (containing $1000 \mu \mathrm{g} / \mathrm{mL}$ ). Double-distilled water served as control. Then, the mixtures were incubated at $(37 \pm 2)^{\circ} \mathrm{C}$ in a BOD incubator (Elite Company) for 15 minutes and then heated at $70^{\circ} \mathrm{C}$ for 5 minutes. After cooling, their absorbance was measured at $660 \mathrm{~nm}$ using ultraviolet-visible spectrophotometer using the vehicle as blank. 78.125, 156.25, 312.5, 625, and $1000 \mu \mathrm{g} / \mathrm{mL}$ concentration of diclofenac sodium was used as reference drug and treated similarly for determination of absorbance [16]. The following formula was used for calculation of percentage inhibition of protein denaturation:

$\%$ inhibition $=100 \times(\mathrm{Vt} / \mathrm{Vc}-1)$

Where, $\mathrm{Vt}=$ Absorbance of test sample, $\mathrm{Vc}=$ Absorbance of control.

\section{RESULTS AND DISCUSSION}

\section{Collection and processing of algae}

Three marine algae samples were collected (Figs. 1-3) and processed to get extracts. These extracts were used for the determination of biological activities.

\section{Determination of biological activities Antibacterial activity}

The increase of microbial resistance to the most commonly used antibiotics isolated from different microorganisms led to testing many other natural resources like algae as an alternative; therefore, it has become an essential to do more screening on some available seaweeds that have a wide distribution on the sea coast. Inhibition zone produced by different algal extracts in well diffusion method was measured and tabulated in Table 1 and shown in Figs. 4 and 5.

From Table 1 methanolic extracts of three marine algae showing better antibacterial activity against E. coli, B. subtilis, P. aeruginosa, and $S$. aureus compared to chloroform extracts and control. G. arcuata showing good antibacterial activity against E. coli, B. subtilis, and $P$. aeruginosa except on $S$. aureus. The methanol extract of seaweeds

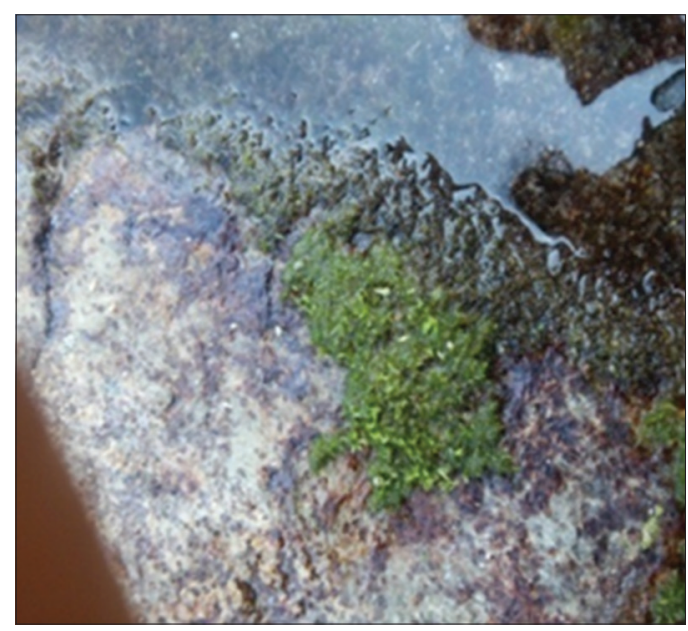

Fig. 1: Enteromorpha compressa 
Table 1: Antibacterial activity of algal extracts against selected test organisms

\begin{tabular}{|c|c|c|c|c|c|c|c|c|}
\hline \multirow[t]{2}{*}{ Marine algae } & \multicolumn{2}{|c|}{ E. coli (IZD in mm) } & \multicolumn{2}{|c|}{ S. aureus (IZD in $\mathrm{mm}$ ) } & \multicolumn{2}{|c|}{ B. subtilis (IZD in mm) } & \multicolumn{2}{|c|}{ P. aeruginosa (IZD in $\mathrm{mm}$ ) } \\
\hline & $\mathbf{M}$ & C & $\mathbf{M}$ & C & $\mathbf{M}$ & C & M & C \\
\hline E. compressa & 25 & 12 & 19 & - & 24 & - & 12 & - \\
\hline U. fasciata & 22 & 14 & 18 & - & 17 & - & 17 & - \\
\hline G. arcuata & 25 & 18 & - & - & 20 & - & 15 & - \\
\hline Control & 14 & 12 & - & - & - & 17 & 14 & - \\
\hline
\end{tabular}

M: Methanol, C: Chloroform, -: No activity, IZD: Inhibition zone diameter, E. compressa: Enteromorpha compressa, U. fasciata: Ulva fasciata, G. arcuata: Gracilaria arcuata E. coli: Escherichia coli, S. aureus: Staphylococcus aureus, B. subtilis: Bacillus subtilis, P. aeruginosa: Pseudomonas aeruginosa

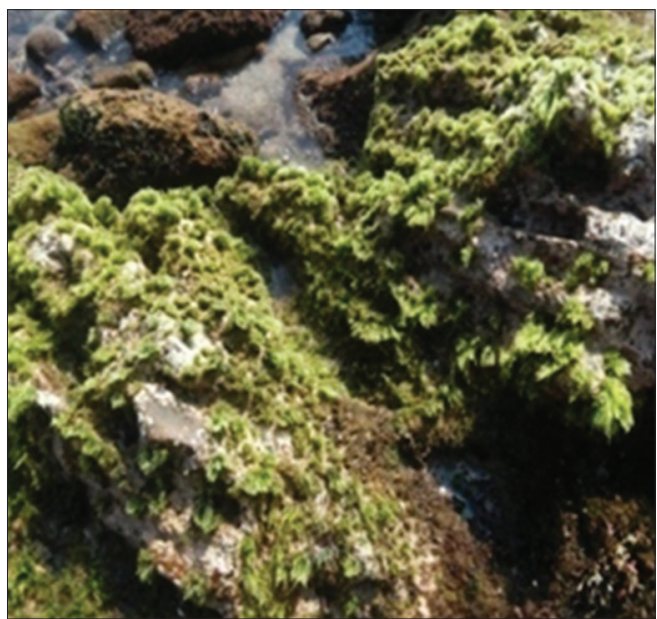

Fig. 2: Ulva fasciata

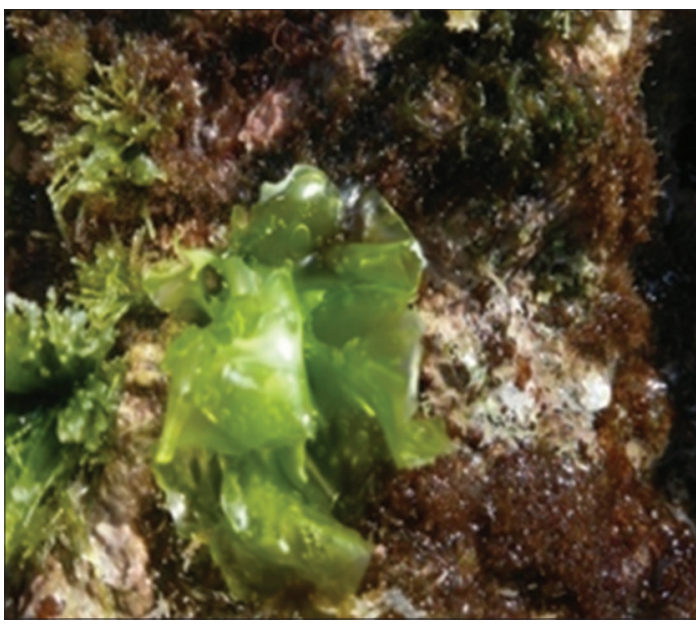

Fig. 3: Gracilaria arcuata

exhibits antimicrobial activity because of the phenolic, alkaloid, and amino acid content [17-19]. Methanolic extract of $U$. fasciata isolated from Visakhapatnam coast has been tested for antibacterial activity against some oral bacteria [20].

\section{Determination of antioxidant activity}

$R P$ method (RP)

From Table 2 and Fig. 6, observed that the methanolic extract of E. compressa showing significant RP activity. Different concentrations of methanolic extract of $E$. compressa antioxidant property were further determined by DPPH free radical scavenging activity. The reducing capacity of a compound is a measure of potential antioxidant activity. For the estimation of the reduced ability, we investigated the Fe3+ to $\mathrm{Fe} 2+$ transformation using the method of Oyaizu, where the change in the optical density of the final mixture is measured at $700 \mathrm{~nm}$. Increase

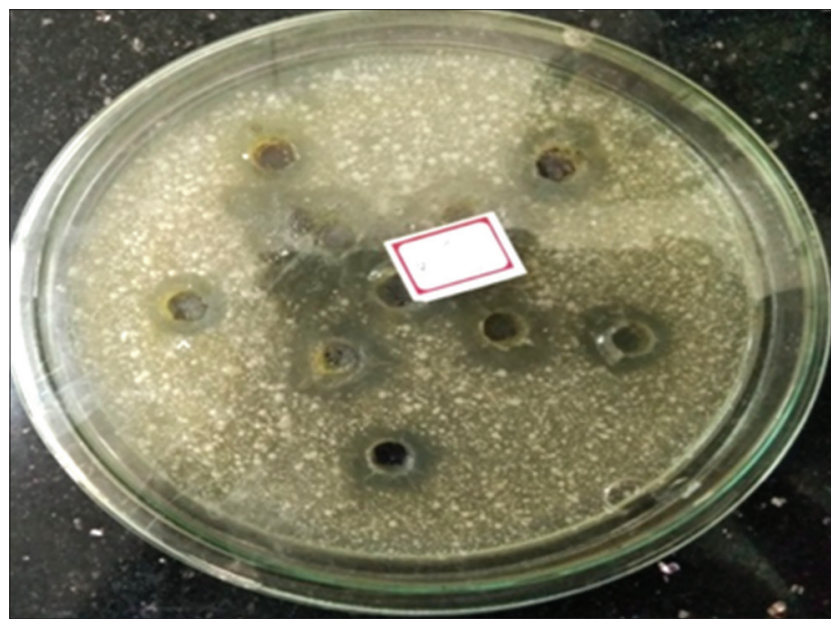

Fig. 4: Antibacterial activity of algae extracts against Escherichia coli

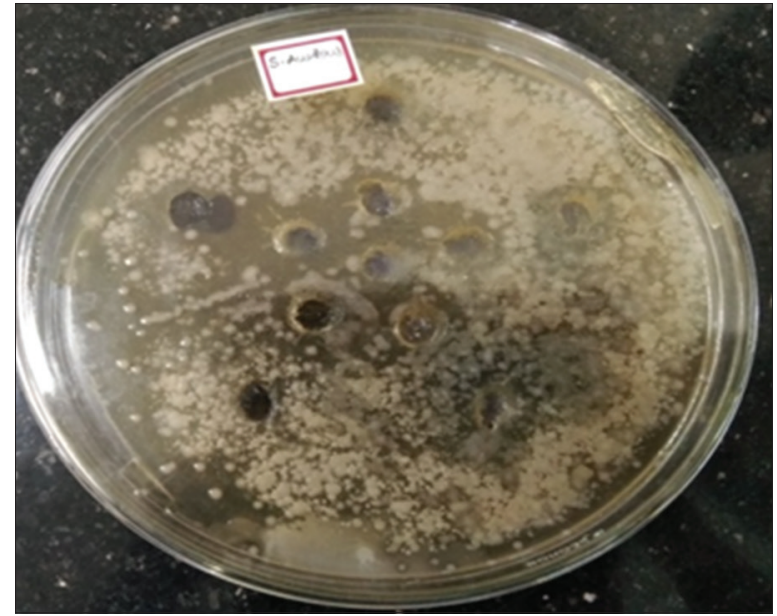

Fig. 5: Antibacterial activity of algae extracts against Bacillus subtilis

in optical density indicates a higher reductive ability [21]. Methanolic extract of Hypnea musciformis red algae isolated from the Rameswaram area reported good significant activity [22]. The reducing capability of the methanolic extract of E. compressa was more significant than the remaining algal extracts.

\section{DPPH radical scavenging activity}

The radical scavenging activity of different concentrations of methanolic extract of $E$. compressa was tested by its ability to decolorize the stable DPPH radical. The principle involved in the present method is the reduction of the alcoholic DPPH solution in the presence of a hydrogen donating antioxidant $(\mathrm{AH})$ due to the formation of nonradical form $\mathrm{DPPH}-\mathrm{H}$ by the reaction $\mathrm{DPPH}+\mathrm{AH} \rightarrow \mathrm{DPPH}-\mathrm{H}+\mathrm{A}$. The remaining 
DPPH measured after a certain time corresponds inversely to the radical scavenging activity of the antioxidant. The sensitivity of the method is determined by the strong absorption of DPPH [23]. Methanolic extract of E. compressa showed a very good antiradical activity in scavenging DPPH radical with a maximum inhibition of about $30.86 \%$ at a concentration of $200 \mu \mathrm{g} / \mathrm{mL}$. Results for the ascorbic acid and sample were tabulated in Table 3 and showed in Figs. 7-9. The standard ascorbic acid showed $86 \%$ inhibition at $200 \mu \mathrm{g} / \mathrm{mL}$ concentration and $33.8 \%$ inhibition at $12.5 \mu \mathrm{g} / \mathrm{mL}$ concentration. Whereas the test sample showed $30.86 \%$ inhibition at $200 \mu \mathrm{g} / \mathrm{mL}$ concentration and $3.35 \%$ inhibition at $12.5 \mu \mathrm{g} / \mathrm{mL}$ concentration. Antioxidant activity of

\section{Table 2: Absorbance values for RP method}

\begin{tabular}{ll}
\hline Name of the algae (dose $\mathbf{1 0 0 0} \mathbf{\mu g} / \mathbf{m L})$ & Absorbance $\mathbf{( 7 0 0 ~} \mathbf{~ m})$ \\
\hline E. compressa & $1.098 \pm 0.24$ \\
U. fasciata & $0.466 \pm 0.19$ \\
G. arcuata & $0.879 \pm 0.16$ \\
Ascorbic acid & $1.176 \pm 0.24$ \\
\hline
\end{tabular}

E. compressa: Enteromorpha compressa, U. fasciata: Ulva fasciata, G. arcuata: Gracilaria arcuata

Table 3: Percentage of inhibition of samples at different concentrations

\begin{tabular}{lll}
\hline Concentration $(\boldsymbol{\mu g} / \mathbf{m l})$ & \multicolumn{2}{l}{ Inhibition percentages } \\
\cline { 2 - 3 } & Ascorbic acid & Sample-1 \\
\hline 200 & $86.62 \pm 0.04$ & $30.86 \pm 0.14$ \\
100 & $72.12 \pm 0.09$ & $26.02 \pm 0.09$ \\
50 & $59.48 \pm 0.19$ & $17.47 \pm 0.09$ \\
25 & $48.7 \pm 0.13$ & $8.92 \pm 0.13$ \\
12.5 & $33.83 \pm 0.05$ & $3.35 \pm 0.11$ \\
\hline
\end{tabular}

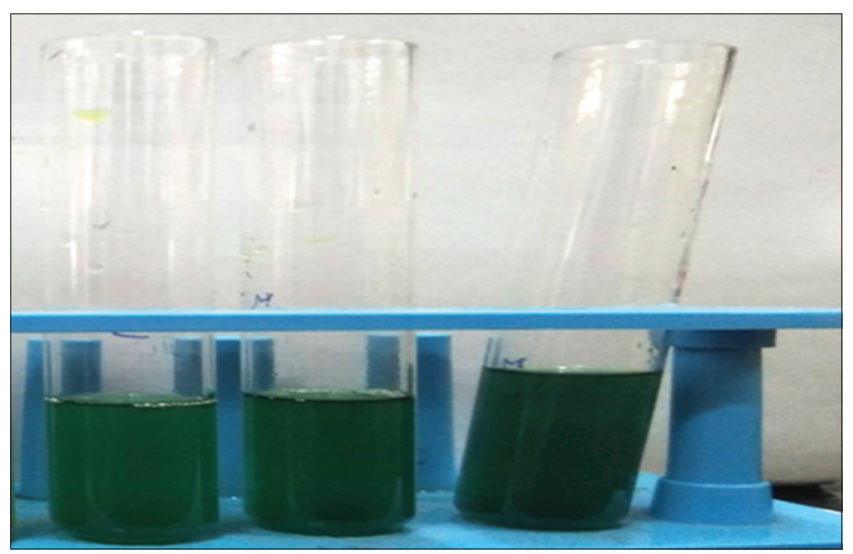

Fig. 6: Reducing power of algal extracts

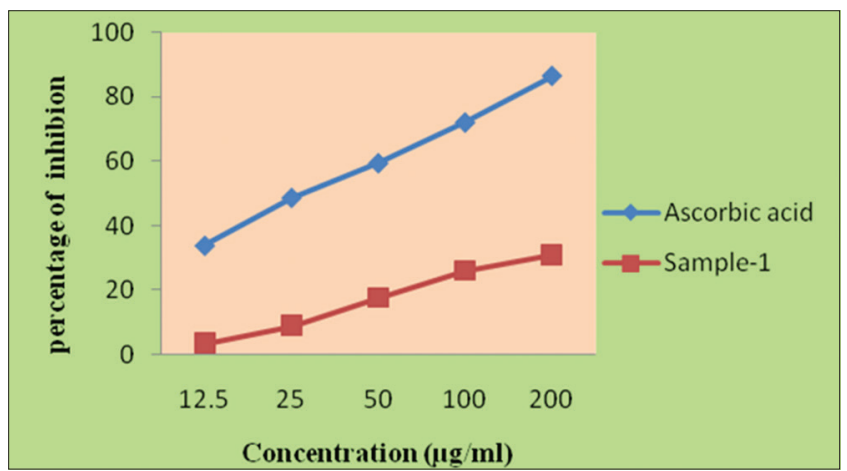

Fig. 7: 1, 1-diphenyl-2-picryl-hydrazil radical scavenging activity of Enteromorpha compressa
U. lactuca and E. intestinalis determined using DPPH radical scavenging method collected from Adriatic coast of Montenegro [24]. Ethyl acetate extracts of E. compressa isolated from Abu Qir bay at Alexandria (Mediterranean Sea) reported 36\% of the marked antioxidant activity compared to the remaining extracts [25].

\section{Determination of anti-inflammatory activity}

HRBC stabilization method

Hypotonicity induced HRBC membrane lysis was inhibited by increased stabilization of HRBC due to the addition of algal extracts having antiinflammatory activity. The percentage of membrane stabilization was measured for methanolic, chloroform extracts of algae and diclofenac sodium at $50,100,250,500$, and $1000 \mu \mathrm{g} / \mathrm{mL}$ concentrations. Methanolic extract of $U$. fasciata is effective in inhibiting the heatinduced hemolysis of human RBC at concentration $1000 \mu \mathrm{g} / \mathrm{mL}$ as shown in Table 4 and showed the maximum inhibition $90.19 \%$ for diclofenac sodium and $36 \%$ for $U$. fasciata. The membrane hemolysis is decreased and membrane stabilization, increased by increasing the concentration of active compounds. Hence anti-inflammatory activity of the extract was concentration dependent. Erythrocyte membrane is almost comparable with that of the lysosomal membrane as the stabilization of erythrocyte membrane implies that the extract may also well stabilize lysosomal membranes so, for estimation of antiinflammatory activity in in vitro HRBC method was selected. Release of lysosomal constituents is inhibited from activated neutrophils by the stabilization of lysosomal membrane which prevents inflammation.

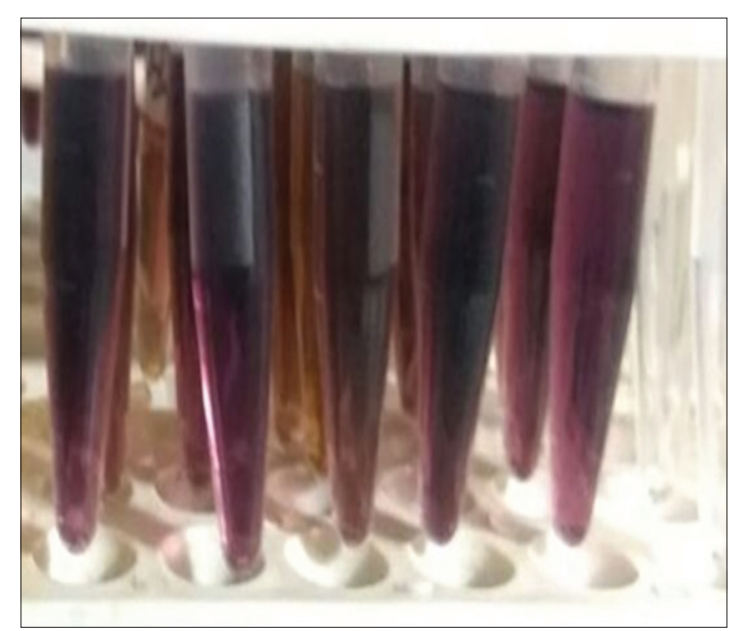

Fig. 8: 1, 1-diphenyl-2-picryl-hydrazil showing purple color before incubation

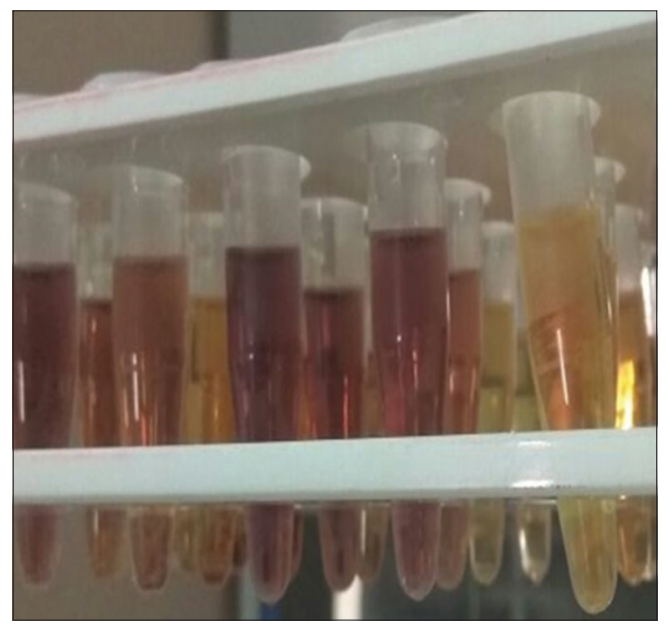

Fig. 9: Decolorization of 1, 1-diphenyl-2-picryl-hydrazil after incubation 
Table 4: \% of protection of standard and algal extracts by HRBC method

\begin{tabular}{|c|c|c|c|c|}
\hline $\begin{array}{l}\text { Diclofenac sodium } \\
\text { DOSES }(\mu \mathrm{G} / \mathrm{mL})\end{array}$ & $\%$ of protection & $\begin{array}{l}\text { Marine algae } \\
\text { doses }(1000 \mu \mathrm{g} / \mathrm{mL})\end{array}$ & $\%$ of protection (methanolic) & $\%$ of protection (chloroform) \\
\hline 50 & 55.21 & E. compressa & - & - \\
\hline 100 & 67.32 & U. fasciata & 36 & 14 \\
\hline 250 & 74.71 & G. arcuata & 34 & - \\
\hline 500 & 82.38 & & & \\
\hline 1000 & 90.19 & & & \\
\hline Control & - & Control & - & - \\
\hline
\end{tabular}

HRBC: Human red blood cell, E. compressa: Enteromorpha compressa, U. fasciata: Ulva fasciata, G. arcuata: Gracilaria arcuata

Table 5: $\%$ of inhibition of algae extracts determined by egg albumin method

\begin{tabular}{lllll}
\hline $\begin{array}{l}\text { Diclofenac } \\
\text { standard }(\boldsymbol{\mu g} / \mathbf{m L})\end{array}$ & \% of inhibition & $\begin{array}{l}\text { Marine algae } \\
\text { dose }(\mathbf{1 0 0 0} \boldsymbol{\mu g} / \mathbf{m L})\end{array}$ & \% of inhibition (chloroform extract) & \% of inhibition (methanolic extract) \\
\hline 78.125 & 14.5 & E. compressa & - & 9.55 \\
156.25 & 28 & U. fasciata & - & 52.82 \\
312.5 & 55 & G. arcuata & & 46.45 \\
625 & 87 & & - & - \\
1000 & 208.5 & Control & & \\
Control & - & &
\end{tabular}

E. compressa: Enteromorpha compressa, U. fasciata: Ulva fasciata, G. arcuata: Gracilaria arcuata

The results of the present investigation suggest that the methanolic extract of the $U$. fasciata exhibiting good anti-inflammatory activity by providing HRBC membrane stabilization when compared to the chloroform extracts of the other marine algae.

\section{Egg albumin method}

Denaturation of tissue proteins is one of the main causes of inflammation and arthritic diseases. Production of autoantigens in certain arthritic diseases may be due to denaturation of proteins in vivo [26]. Bioactive compounds that can prevent protein denaturation, therefore, would be beneficial for the development of anti-inflammatory drugs. When compared to the control, there were increments in absorbance of test samples indicated the stabilization of protein or inhibition of heatinduced protein (albumin) denaturation by algae extracts and reference drug diclofenac sodium [27]. Methanol extracts of Undaria pinnatifida and Ulva linza reported better inflammatory activity [28]. Therefore, from the results (Table 5) of the present study, it can be concluded that $U$. fasciata possessed marked in vitro anti-inflammatory effect against the denaturation of the protein.

\section{CONCLUSION}

Tested algal extracts have a certain level of antibacterial, antioxidant, and anti-inflammatory activity. Methanolic extracts of algae have remarkable activity compared to chloroform algal extracts. Based on the above results the selected macroalgae are the good source of bioactive compounds. These bioactive compounds containing macroalgae may find their commercial potential in medicine, food, and cosmetic industry. Further definitive studies are necessary to ascertain the mechanisms and constituents behind its antibacterial, antioxidant, and anti-inflammatory actions.

\section{REFERENCES}

1. Lee J, Ko N, Min DB. Reactive oxygen species, aging, and antioxidative nutraceuticals. Compr Rev Food Sci Food Saf 2004;3:21-33.

2. Zbakh H, Chiheb H, Bouziane H, Sanchez VM, Riadi H. Antibacterial activity of benthic marine algae extracts from the Mediterranean coast of Morocco. J Microbiol Biol Food Sci 2012;2(1):219-28.

3. Bouhlal R, Haslin C, Chermann JC, Colliec-Jouault S, Sinquin C, Simon G, et al. Antiviral activities of sulfated polysaccharides isolated from Sphaerococcus coronopifolius (Rhodophytha, Gigartinales) and Boergeseniella thuyoides (Rhodophyta, Ceramiales). Mar Drugs 2011;9(7):1187-209.

4. Na HJ, Moon PD, Lee HJ, Kim HR, Chae HJ, Shin T, et al. Regulatory effect of atopic allergic reaction by Carpopeltis affinis. J Ethn
2005;1(101):43-8

5. Dayong S, Jing L, Shuju G, Lijun H. Antithrombotic effect of bromophenol, the alga-derived thrombin inhibitor. J Biotechnol 2008:136:577-88

6. Kim SK, Thomas NV, Li X. Anticancer compounds from marine macroalgae and their application as medicinal foods. Adv Food Nutr Res 2011;64(64):213-24

7. Bhadury P, Wright PC. Exploitation of marine algae: Biogenic compounds for potential antifouling applications. Planta 2004;219(4):561-78.

8. Devi GK, Manivannan K, Thirumaran G, Rajathi FA, Anantharaman P. In vitro antioxidant activities of selected seaweeds from Southeast coast of India. Asian Pac J Trop Med 2011;4(3):205-11.

9. Kharkwal H, Joshi DD, Panthari P, Pant MK, Kharkwal AC. Algae as future drugs. Asian J Pharm Clin Res 2012;3(5):1-4.

10. Kolanjinathan K, Ganesh P, Saranraj P. Pharmacological importance of seaweeds. World J Fish Mar Sci 2014;6(1):10-5.

11. Rani DS, Rao PY, Sirisha IR. Distribution of seaweeds along the coastal waters of Visakhapatnam, east coast of India. J Int Acad Res Multidiscip 2015;3(1):154-62

12. Jayaprakash GK, Singh RP, Sakariah KK. Antioxidant activity of grape seed extracts on peroxidation models in vitro. Food Chem 2001;3(73):285-90.

13. Oyaizu M. Studies on products of browning reaction prepared from glucosamine. Jpn J Nutr 1986;44:307-14.

14. Zhang WW, Duan XJ, Huang HL, Zhang Y, Wang BG. Evaluation of 28 marine algae from the Quingdao coast for anti-oxidative capacity and determination of antioxidant efficiency and total phenolic content of fractions and sub fractions derived from Symphyocladia latiuscula (Rhodomelaceae). J Appl Phycol 2007;19(2):97-108.

15. Vana JR, Botting RM. New insight into the mode of action of antiinflammatory drugs. Inflamm Res 1995;1(44):1-10.

16. Bhattacharya S, Chandra S, Dey P, Chatterjee P. Evaluation of in vitro anti-inflammatory activity of coffee against the denaturation of protein. Asian Pac J Trop Biomed 2012:1(2):178-80.

17. Meenakshi S, Gnanambigai DM, Mozhi ST, Arumugam M, Balasubramanian T. Total flavanoid and in vitro antioxidant, antibacteria from seaweeds of Rameshwaram coast. Glob J Pharm 2009;3(2):59-62.

18. Cox S, Abu-Ghannam N, Gupta S. An assessment of the antioxidant and antimicrobial activity of six species of edible Irish seaweeds. Int Food Res J 2010;17:205-20.

19. Srivastava N, Saurav K, Mohanasrinivasan V, Kannabiran K, Singh M. Antibacterial potential of macroalgae collected from the Madappam coast, India. Br J Pharm Toxicol 2010;1(2):72-6.

20. Sujatha L, Govardhan TL, Rangaiah GS. Antibacterial activity of green sea weeds on oral bacteria. Indian J Nat Prod Res 2012;3(3):328-33

21. Repetto MG, Liesuy SF. Antioxidant properties of natural compounds used in popular medicine for gastric ulcers. Braz J Med Biol Res 2002;35(5):523-34. 
22. Pandian A, Baskaran K, Subashini R. Free radical scavenging and antioxidant properties of marine red algae hypnea musciformis. Int $\mathbf{J}$ Pharm Pharm Sci 2015;7(8):227-31.

23. Satoskar RS, Bhandarkar SD, Ainapure SS. Pharmacology and pharmacotherapeutics. In: Pharmacotherapy of Gout, Rheumatoid Arthritis and Osteoarthritis. $18^{\text {th }}$ ed. Mumbai: Popular Prakasham Publication; 2003.

24. Marijana K, Branislav R, Tatjana S. Biological activities of two macroalgae from Adriatic coast of Montenegro. Saudi J Biol Sci 2015;22(4):390-7.

25. Shalaby EA, Shanab AM, El-Fayoumy EA. Enteromorpha compressa exhibits potent antioxidant activity. J Biomed Biotechnol 2011;726405:1-11
26. Umapathy E, Ndebia EJ, Meeme A, Adam B, Menziura P, Nkeh-Chungag BN, et al. An experimental evaluation of Albuca setosa aqueous extract on membrane stabilization, protein denaturation and white blood cell migration during acute inflammation. J Med Plant Res 2010;4(9):789-95

27. Jatap VA, Agasimundim YS, Jayachandran E, Sathe BS. In vitro anti-inflammatory activity of 2-amino-3-(substituted benzylidinecarbohydrazide)-4,5,6,7-tetrahydrobenzothiophene. J Pharm Res 2011;4(2):378-9.

28. Priyadarsini PM, Satyabrata DS, Lakshman N, Ranjan PC. Uses of seaweed and its application to human welfare: A review. Int J Pharm Pharm Sci 2016;8(10):12-20. 